\title{
The Student Teachers' Verbal and Non-Verbal Reinforcement During Teaching Practice in Microteaching Class
}

\author{
Ali Mas'ud \\ Faculty of Teacher Training and Education \\ Universitas Islam Negeri Sunan Ampel \\ Surabaya, Indonesia
}

\author{
Di Adha Wulandari \\ English Teacher Education Department \\ Universitas Islam Negeri Sunan Ampel \\ Surabaya, Indonesia
}

\begin{abstract}
This qualitative research aimed to know types of verbal and non-verbal reinforcement given by student teachers in microteaching class and to describe the way student teachers give the reinforcements during their teaching practice in microteaching class. The data were collected through observation, interview and student teachers' teaching practice videos by involving 8 student teachers from A-H microteaching classes. This research revealed that student teachers gave both verbal and non-verbal reinforcement. Furthermore, the finding also showed that student teachers gave reinforcement through four ways such as to individual, to group, as soon as students performed desirable behavior and use reinforcement in various types and patterns. This research suggests that student teachers need to pay attention on keeping eye contact, mentioning student's name, and stating students' wished behavior while giving reinforcement.
\end{abstract}

Keywords: reinforcement, verbal reinforcement, nonverbal reinforcement, teaching practice, student teacher, microteaching

\section{INTRODUCTION}

A teacher is expected to have good teaching skills in order to conduct an effective teaching and learning process. Uzer Usman stated that there are eight basic teaching skills that must be mastered by a teacher. Those are questioning, reinforcement, variation, explaining, close and set induction, coaching small group discussion, classroom management, teaching small group and individual. These eight basic teaching skills play important role in a successful teaching and learning.

One of necessary basic teaching skills is reinforcement. Slavin stated that reinforcement is any consequence that strengthens behavior. Similarly, Uzer Usman defined reinforcement as teacher's positive response towards students' behavior. To put it simply, reinforcement is a skill to response students' behavior during teaching and learning process. A teacher needs to know reinforcement skill which can be a stimulus for students to improve their performance. In teaching and learning process, reinforcement is given as an appreciation or positive response of the teacher towards students' intended behavior, participation, and achievement.

Uzer Usman divided reinforcement into two called verbal and non-verbal reinforcement. Verbal reinforcement is given through words or sentences as like complementing students or congratulating them for what they have done. While, non-verbal reinforcement is given through gesture, proximity, activity, token/symbol, and contact. Irawan stated that teacher must owned reinforcement skill because reinforcement provides support for students to improve their performance. In addition, reinforcement skill is important for teachers, as it can increase students' motivation and active participation in learning which can help them to have an effective teaching-learning. It is supported by Moore who explained that reinforcement is a long recognized and essential skill for classroom teacher. It means that reinforcement is one of important aspects to support learning process run well.

In order to produce professional teachers, Tarbiyah and Teacher Training Faculty conducted PPL (Program Pengalaman Langsung) which commonly known as peer teaching, teaching practice or microteaching. This program is proposed as a program to train the teacher candidates about basic teaching skills and teaching competences including reinforcement skill. Based on the preliminary data, during teaching practice program (PPL 1) academic year 2017/2018 in microteaching class at UIN Sunan Ampel Surabaya, it was found that most of student teachers had performed reinforcement in their teaching practice. It could be seen from their teaching practice performance that was done by student teachers while practicing teaching practice in Microteaching class. For instance, student teachers praised them by saying "you are very smart", "good" and the like as verbal 
reinforcement. Likewise, student teachers gave the students reward, applause, smile and the like as non-verbal reinforcement. However, some student teachers who took a role as the teacher had not been able to give reinforcement optimally. It could be seen from their teaching practice performance. For example, student teacher did not mention student's name while praising him for his correct answer. As the result, students were confused and felt not appreciated especially for student who gave correct answer. Furthermore, if the same case happens in real classroom it may cause ineffective teaching-learning and students' demotivation. So that, giving reinforcement appropriately is very important especially for student teachers as teacher to be in the future. As that problem occurred, it is essential to have further research on types of verbal and non-verbal reinforcement along with how student teachers gave the reinforcement. For this reason, researcher is interested on this phenomenon and is going to conduct a research on reinforcement specifically in English teaching-learning done by EFL student teachers' during teaching practice (PPL 1) academic year 2018/2019 in microteaching class at ETED (English Teacher Education Department) of UIN Sunan Ampel Surabaya.

There are some researchers that have been conducted on reinforcement which covered reinforcement in relation to students' motivation, its influence on students' academic achievement, reinforcement in speaking activity, and teacher's variation in giving reinforcement. Therefore, to fill the gap this study is interested in investigating the topic qualitatively and poses the following research questions: (1) What are the types of verbal and non-verbal reinforcement given by student teachers during teaching practice in microteaching class? (2) How do student teachers give verbal and non-verbal reinforcement during teaching practice in microteaching class?.

Practice teaching (PPL 1) also refers to microteaching which defined as a program which enables students to practice teaching skills. Both practice teaching (PPL 1) and microteaching have the same meaning. Here, researcher will often use the term practice teaching as it is commonly used by English Education Department at UIN Sunan Ampel Surabaya in defining PPL 1 rather than the term microteaching. Practice teaching program gives opportunities for the teacher candidates to develop their teaching skill and to apply material about teaching that have been taught in the previous semester.

Teaching practice is an informal practice of certain teaching technique with other training student in order to assed a lesson formally. It also can be defined as the name of student teachers' preparation for teaching by practical training. Teaching practice is an essential component of teacher training program since it provides first teaching experience which is useful for student teachers' professional life.

According to Buku Pedoman Praktik Pengalaman Lapangan II (PPL II), student teacher is a student who enrolled teaching practice class. Student teachers have multiple roles when they are entering practice teaching class.
Here, student teachers play role as a teacher in a real-like classroom setting during their practice teaching, a student when their peers play role as the teacher, and as an observer who provides feedback for another student who become a teacher at the time.

Positive reinforcement is type of reinforcement in which a wished behavior or any acceptable result follows a reaction and make it possible that the behavior will be repeated in the future. The use of positive reinforcement increases the possibility of a behavior to be repeated again and again. Praise, house points, or freedom to choose an activity belong to reinforcers in education field that are used as reward for desirable behavior. Negative reinforcement is type reinforcement in which strengthen a desirable behavior by removing unpleasant thing or situation. Besides, it also can be defined as a method used to decrease undesirable behavior by pairing it with pleasant consequence. For example, a teacher gives a fewer homework to students in order to decrease students' stressful feeling of doing abundant homeworks continuously.

Reinforcement is one of basic teaching skills that have to master by a teacher to encourage students in learning. According to Uzer Usman, reinforcement is any response both in verbal and non-verbal which modify students' behavior in order to give feedback on their behavior either as a support or correction. In the field of foreign language teaching, teacher's reinforcement is part of appreciations and methods used by the teacher to maintain students' attention towards classroom activities and to motivate them towards learning. Imitation, reinforcement, and rewarding are basic strategies of language learning in scope of behaviorist theory. Hence, reinforcement is one of components in behaviorism theory which views language as stimulus and response.

There are two types of reinforcement namely verbal and non-verbal reinforcement. When the teacher use facial expression like smile and body movement like hand clapping to reinforce student, it is called non-verbal reinforcement. In another hand, when teacher praised student for their achievement through words such as great, nice and the like, it refers to verbal reinforcement. Stimulating and encouraging students' performance during classroom activity in acquiring knowledge are the ultimate aim of reinforcement in teaching and learning including in ELT classroom. There are many students find difficulty to learn English. In this case, reinforcement can be used as support to motivate them in learning English better. In addition, reinforcement in ELT classroom also can be a tool to manage students' misbehavior during classroom teaching. Gerson stated that giving reinforcement is a strategy to modify students' behavior and to reinforce students' response in learning. The use of reinforcement modifies students' behavior positively as it makes students realized that certain behavior is desirable. Once they realized it, they tend to repeat the same or similar behavior later.

There are some purposes of giving reinforcement such as increase students' attention in learning, make learning process easier, maintain students' motivation, control 
students' misbehavior, develop and manage one-self in learning, guide students to divergent thinking and selfinitiative. Such purposes help teacher in conducting an effective teaching and learning.

Uzer Usman stated that reinforcement is divided into two namely verbal reinforcement and non-verbal reinforcement. Verbal reinforcement is usually expressed in form of praising words, appreciation, agreement and the like. For instance, good; very good; correct; smart; yes, a hundred for you !. Besides words, verbal reinforcement can also be given in form of sentence as like you present the material well, you are talented student and the like.Non-verbal reinforcement do not use any kinds of expression like in verbal reinforcement instead of using reinforcement through gesture, proximity, contact, activity, and token/symbol.

1) Gestural Reinforcement, involves the use of facial expression like smile, laugh, delightful. Besides that, bodily expressions as like nodding, thumbs up, clapping and the like can also be used.

2) Proximity Reinforcement, involves teacher's action which reflect her/his interest in students' performance by moving nearer, standing next to or sitting close to students.

3) Contact Reinforcement, involves wiping student's head, hand shake or raising student's hand in the class.

4) Activity Reinforcement, involves teacher's decision to let student chose any activity that they prefer as reinforcement for work.

5) Token/symbolic Reinforcement, involves teacher's decision to give awards, marks sweet comment on books and etc.

There are several principals that should be noticed by a teacher in giving reinforcement both verbal and non-verbal are warmth, enthusiasm, meaningful, and avoid the use of negative response. It is important to make sure that the student feels the sincerity of the reinforcement given.

It is essential for teacher to know when to give reinforcement to students as it can help teacher to provide effective reinforcement. It can be given in various conditions during teaching and learning process in the class. Specifically, when students perform the desired behavior and show their improvement in learning. By giving reinforcement, students will be more engaged and motivated in learning. Teacher can deliver reinforcement when students are paying attention during the class, students doing classroom activities, students have accomplished their assignment either fully or partially, students are doing their task with a good quality and so on.

The way to give reinforcement also should be taken into count as it help teacher to give the reinforcement effectively to students. It is divided into four such as individual reinforcement, group reinforcement, immediacy in giving reinforcement and variation in giving reinforcement. Individual reinforcement refers to reinforcement which given to student individually. While, group reinforcement is given to students in group. In giving reinforcement both individual and group, it is important to look at student's eyes, mention student's name, make it clear to whom the reinforcement is given and mention student's desirable behavior. Reinforcement should be given as soon as students performed intended behavior to maintain its value. In addition, combine different types of reinforcements such as verbal and nonverbal and its pattern help teacher to avoid giving reinforcement in monotonous ways.

\section{METHOD}

This research employed qualitative method with naturalistic approach. The data were obtained through observation, interview and student teachers teaching practice videos. Next, the data which had been gathered were analyzed qualitatively by using data analysis technique from Cresswell. In addition, reinforcement theory from Uzer Usman in theoretical framework was also used to examine, support,and analyze the data in research discussion. This research was done at UIN Sunan Ampel Surabaya, especially in Microteaching class of English Education Department academic year $2018 / 2019$ by involving 8 student teachers from 8 different microteaching classes available.

\section{FINDINGS AND DISCUSSION}

\section{(A) Findings}

(1) Types of Verbal and Non-verbal Reinforcement in Microteaching Class

a. Verbal Reinforcement

The result of observation, interview and student teachers' teaching practice videos revealed that all of student teachers gave verbal reinforcement in their teaching practice. It was in form of word and sentence. The student teachers gave reinforcement to student when they can answer a question correctly, perform good behavior and collect highest point in the class. The word-type reinforcements given by student teacher during their teaching practice were good, great, right, and correct. It also supported by the result of interview where totally 8 student teachers agree on giving reinforcement through words. In another hand, the sentence-type reinforcements performed by teacher were "I think your suggestion is amazing... ", "It's gonna be good", "Yeah, that's the correct one", "thank you for the volunteer", "everyone has a god argument", "that's the correct answer Nurul", and "good job for group one”. In contrast, only 6 of 8 student teachers gave verbal reinforcement using sentences. Similarly, from the interview some student teachers approved that they delivered reinforcement through words instead of sentences. 
was done for both verbal and non-verbal reinforcements which given to students as individual, group and pair. Student teachers gave reinforcement immediately when students were able to answer a question correctly, do their work well, behave well and get highest point in the class.

d. Variation

The result of this research found that all of student teachers gave variation in giving reinforcement during their practice teaching. The variation was not only in term of types of reinforcements used but also in term of patterns. Here, student teachers combined various reinforcements during their teaching. For example, they gave reinforcement through smile and applause or nod, applause and praise word and so forth. In addition, student teachers also varied to whom the reinforcement is given to such as to individual, group, and the whole class. practice teaching such presentation, game, and displaying students' work in front of the class. For the token or symbol reinforcement student teachers gave emoticon, love and star to students' work as evaluation and appreciation. Additionally, only 4 student teachers performed token or symbol reinforcement. However, the result of observation and interview showed that none of the student teachers gave contact reinforcement in their teaching practice.

(2) The Way Verbal and Non-verbal Reinforcement Given in Microteaching Class

a. Individual Reinforcement

The result of the study revealed that all of student teachers gave reinforcement to individual. Even though, only 3 student teachers including ST D, ST F, and ST G who gave reinforcement by mentioning student's name, pointing out to a student clearly, stating student's desirable behavior, and keeping eye contact with student in giving individual reinforcement during their teaching practice.

b. Group Reinforcement

It was found that only 4 student teachers gave reinforcement to students in a group. They were ST A, ST C, ST F and ST G. Additionally, they all gave group reinforcement in the same was as individual reinforcement. In another hand, the rest of student teachers gave reinforcement to students in pair as the preferred activity was pair work.

c. Immediacy

The data showed that all student teachers gave reinforcement as soon as student performed desirable behavior during teaching session. It
(B) Discussion

1. Types of Verbal and Non-verbal Reinforcement in Microteaching Class

Student teachers gave both verbal and nonverbal reinforcement in microteaching class. It was in line with Uzer Usman's theory on reinforcement. He stated that verbal reinforcement usually expressed in form of praising words, appreciation, agreement and the like. Besides, praising sentences could also be used in reinforcing students. Moreover, giving non-verbal reinforcement is one of alternative ways in reinforcing students. He stated that facial expression like smile and body movement like giving applause are gestural reinforcement which can be provided by teacher in reinforcing students. When student teachers came closer to students, it reflected their attention to the students as they gave proximity reinforcement. Student teachers also provided several activities for students such as games, debate activity, and displayed students' work to reinforce students' understanding on the material that had been taught. It means that giving reinforcement can be done through fun activities on lesson that students learned. Besides, token/symbol reinforcement is done by using various things such as emoticon card, star, or sweet comment on students' book. It was in line with the result of observation which showed that in token or symbol reinforcement, student teachers used emoticon, star, and love. In addition, Weiner stated that token reinforcement like giving stikers, stars, pictures, smily face, money, book and pen encourage students in learning. Doing physical contact such as shaking hand, tapping student's shoulder and the like are part of non-verbal reinforcement. But then, such kinds of 
reinforcements were not found in student teachers' teaching practice.

2. The Way Verbal and Non-verbal Reinforcement Given in Microteaching Class

Uzer Usman suggested reinforcement is given in four ways including individual reinforcement, group reinforcement, immediacy and variation. In line with it, student teachers had delivered reinforcements through those four ways in their teaching practice. Reinforcement should be given clearly by mentioning student's name, pointing out clearly to a student, keeping eye contact with the student and stating student's desirable behavior to identify the specific behavior for which the reinforcement was being delivered. It was reflected on student teachers teaching practice. The use of group reinforcement could increase students' motivation in learning. Giving reinforcement immediately will keep its value and make it more effective to students. Furthermore, providing various reinforcements will avoid students from boredom of receiving the same reinforcement for a couple times.

\section{CONCLUSION}

Based on the research that had been done, student teachers gave both verbal and non-verbal reinforcement during their teaching practice in microteaching class. This research revealed that student teachers used word-type and sentence-type reinforcement as verbal reinforcement. In addition, types of non-verbal reinforcement performed by student teachers were only 4 of 5 non-verbal reinforcements which include gesture, proximity, activity, and token/symbol. Furthermore, this research found that student teachers gave reinforcement through four ways such as to individual, to group, as soon as students performed desirable behavior and combine two types of reinforcement, verbal and non-verbal reinforcement at the same time while giving reinforcement in microteaching class. This research suggests that student teachers need to pay attention on keeping eye contact, mentioning student's name, and providing reason why student is reinforced.

\section{REFERENCES}

[1] Aijaz Ahmed Gujjar, Bushra Naoreen, Saifullah Saifi, \& Muhammad Jamil Bajwa, "Teaching Practice: Problems and Issues in Pakistan". International Online Journal OfEducationalm Science. Vol 2, No. 2, February 2010, 339.

[2] Alan Pritchard,Ways Of Learning: Learning Theories and Learning Styles in The Classroom, Second Edition. (New York: Routledge, 2008), 15.

[3] B. Weiner. " A Theory Of Motivation For Some Classroom Experiences". Journal of Educational Psychology, Vol. 7, No. 1, 1973.

[4] Des Yatim, "Penggunaan Penguatan dalam Pembelajaran BidangS tudi PPKN di Kelas IX 10 Tenggarong", Cendekia, 10(1): 79-90. 2016

[5] E. C.Wragg, Primary Teaching Skills (UK: ROUTLEDGE, 2005), 29.

[6] Hubbard Jones \&Thomton Wheeler, A Training Course for TEFL, (UK: Oxford UniversityPress, 1983).

[7] GersonRatumanan, BelajardanPembelajaran(Surabaya: UNESA University Press, 2002), 76

[8] GulapSahzada, MazharUllahDawar\&ZakiahTanzeela Fatimah, "Perceived Effect of...., p. 14.

[9] Louis Cohen., et all. A guide to Teaching Practice, Fifth edition (USA: Taylor and e-Francis, 2010), 331.

[10] Mohammed Rashel Uddin, "Influence Of Reinforcement In English Language Learning aat Primary Level of Education in Bangladesh" BELTA Journal, Vol. 1, No. 1, 2017, 85.

[11] Prasety Irawan, Teori Belajar, Motivasi, dan Ketrampilan Mengajar (Jakarta: Dirjen Dikti Departemen Pendidikan dan Kebudayaan, 1997). 62.

[12] Roger Gower, Diana Philips and Steve Walters.Teaching Practice: A handbook for Teachers in Training. Macmillan books for teacher.

[13] Santrock, Educational Psychology: Classroom Update: Preparing for Praxis and Practice, 218-219.

[14] Slavin, Educational Psychology: Theory and Practice.

[15] Suyono-Hariyanto, Belajar dan Pembelajaran (Bandung: PT Remaja Rosyda Karya, 2012), 226-227.

[16] SyaifulBahriDjamarah, Guru danAnakDidik: SuatuPendekatanTeoritisPsikologis (Jakarta: PT RinekaCipta, 2005), 119.

[17] Uzer Usman, Menjadi Guru Profesional (Bandung: PT RemajaRosydaKarya, 2005). 